\title{
EVALUASI FUNGSI HATI PADA PASIEN HIV/AIDS DENGAN TERAPI ARV DI RSUD MANGUSADA
}

\section{(EVALUATION OF LIVER FUNCTION IN HIV/AIDS PATIENTS WITH ARV THERAPY AT MANGUSADA HOSPITAL)}

\author{
HERLEEYANA MERIYANI*•, NI NYOMAN WAHYU UDAYANI*, KETUT AGUS ADRIANTA*
}

*Akademi Farmasi Saraswati Denpasar, Jalan Kamboja no. 11A, Denpasar, Bali

\begin{abstract}
Abstrak: Penyakit HIV/AIDS merupakan masalah kesehatan dunia karena menyebabkan angka kematian yang tinggi. Penyakit HIV/AIDS dapat menjangkit seluruh lapisan masyarakat dan semua kelompok umur. Salah satu efek samping dari penggunaan ARV yaitu terjadinya gangguan fungsi hati pada ODHA. Penilaian evaluasi penggunaan terapi ARV terhadap gangguan fungsi hati dapat dilihat dari kadar SGPT/SGOT. Penelitian ini bertujuan untuk mengetahui pengaruh mengevaluasi derajat kerusakan hati pasien HIV/AIDS dengan ARV serta untuk mengetahui pengaruh nevirapin terhadap efek peningkatan enzim SGOT dan SGPT. Jenis/desain penelitian ini merupakan penelitian studi cross sectional. Evaluasi fungsi hati dilakukan dengan melihat pemeriksaan fungsi hati pasien yang tercantum dalam rekam medis. Setelah data SGOT dan SGPT terkumpul maka akan dievaluasi apakah gangguan fungsi hati dengan menggunakan penggolongan toksisitas ARV yang ditetapkan oleh kementerian Kesehatan Republik Indonesia. Kemudian untuk melihat perbandingan fungsi hati masing masing regimen akan dlakukan secara statistika dengan taraf kepercayaan 95\%. Penelitian ini menggunakan teknik purposive sampling. Subjek yang menjadi sampel penelitian yaitu berjumlah sebanyak 63 pasien, yang terdiri atas laki-laki $62 \%$ dan $38 \%$ perempuan. sebanyak 84,10 pasien HIV/AIDS yang memperoleh terapi ARV tidak mengalami gangguan hepar, sisanya mengalami toksisitas ringan dan sedang. Penggunaan nevirapin tidak berpengaruh secara signifikan terhadap peningkatan SGOT dan SGPT p>0,05; OR 0,833 (CI 0,192-3,614).
\end{abstract}

Kata Kunci: Fungsi Hati, HIV/AIDS, Terapi Antiretroviral (ARV).

\begin{abstract}
HIV / AIDS is a world health problem because it causes a high mortality rate. HIV / AIDS can infect all age groups. One of the side effects of ARV use is the liver dysfunction in PLWHA. Assessment of the evaluation of the use of ARV therapy for impaired liver function can be seen from the level of SGPT and SGOT. The aims of this study are to determine the degree of liver damage of HIV / AIDS patients with ARVs and to determine the effect of nevirapin towards the level of SGOT and SGPT enzymes. This study is a cross sectional study. Evaluation of liver function was carried out by examining the liver function of patients listed in the medical record. After the SGOT and SGPT data were collected, it will be evaluated whether the liver function is impaired by using the classification of ARV toxicity established by the Ministry of Health of the Republic of Indonesia. Then to see the comparison of liver function each regimen will be performed statistically with a 95\% confidence level. This study uses purposive sampling technique. The subjects who were the sample of the study were 63 patients, consisting of $62 \%$ male and $38 \%$ female. as many as $84.10 \mathrm{HIV}$ / AIDS patients who received ARV therapy did not experience liver problems, the rest experienced mild and moderate toxicity. The use of nevirapine did not significantly influence the increase in SGOT and SGPT p> 0.05; OR 0.833 (CI 0.192-3.614)
\end{abstract}

Keywords: Antiretroviral Therapy (ART), HIV / AIDS, Liver Function

\section{PENDAHULUAN}

Saat ini HIV (Human Immunodeficiency

Virus)/ AIDS (Aquired Immunodeficiency

Syndrome) masih menjadi masalah global di seluruh dunia. Jumlah penderita HIV didunia meningkat setiap tahunnya dan berdasarkan data WHO 2015, jumlah penderita HIV di seluruh dunia yang sedang dalam terapi antiretroviral sebanyak 17 juta jiwa (WHO 2016). Dalam Global Health

\footnotetext{
- Author correspondence. e-mail: ching25.lee@ gmail.com
} 
Sector and Strategy on HIV, WHO menyampaikan bahwa komunitas internasional berkomitmen untuk mengakhiri epidemic AIDS sebagai ancaman kesehatan masyarakat di tahun 2030 (WHO, 2016). Salah satu strategi yang ditempuh yaitu dengan pendekatan people centered treatment approach dibangun dengan landasan hak asasi dan keseimbangan kesehatan. Diharapkan strategi ini mampu menurunkan kasus HIV baru dan menurunkan kematian akibat HIV. Terapi HIV jangka panjang juga memerlukan pendekatan yang komprehensif terhadap ODHA (orang dengan HIV/ AIDS) (WHO, 2016).

Di Indonesia sendiri kasus HIV/AIDS juga terlihat meningkat setiap tahunnya. Berdasarkan data kenentrian kesehatan Republik Indonesia, pada tahun 2014 tercatat 32.711 kasus HIV baru (Kemenkes, 2016). Terapi HIV/AIDS merupakan terapi berkepanjangan dan memerlukan pendeatan yang komprehensif. Terapi jangka panjang juga perlu dimonitoring efek samping ataupun gejala toksisitas ARV pada pasien. Pemantauan derajad toksisitas dibagi menjadi tahap 1 (ringan), Tahap 2 (sedang), tahap 3 (berat), dan tahap 4 (potensial mengancam jiwa). Penggunaan regimen ARV yang terdiri dari beberapa obat ARV dalam jangka panjang memerlukan perhatian khusus. Salah satunya adalah monitoring fungsi hati. Monitoring fungsi hati dilakukan dengan memantau SGOT dan SGPT.

Memantau fungsi hati setiap 6 bulan sekali pada pasien HIV/AIDS yang mengkonsumsi ARV sangat disarankan. Hal ini karena pada pasien HIV/AIDS kerap menggunakan obat ARV kombinasi dan obat lain seperti antibiotic kotrimoksasol, obat antituberculosis dan lain lain (Pathania et al, 2017). Berdasarkan hasil pemeriksaan SGOT dan SGPT derajat toksisitas akibat penggunaan obat ARV dibagi menjadi 4 tingkat yaitu: toskisitas ringan, sedang, berat dan mengancam jiwa. Rincian derajat hepatotoksisitas dapat dilihat pada tabel 1 .

Tabel 1. Penggolongan Derajat Hepatotoksisitas ARV (Kemenkes, 2014)

\begin{tabular}{ccccc}
\hline Pemeriksaan & $\begin{array}{c}\text { Toksisitas } \\
\text { ringan }\end{array}$ & $\begin{array}{c}\text { Toksisitas } \\
\text { sedang }\end{array}$ & $\begin{array}{c}\text { Toksisitas } \\
\text { tinggi }\end{array}$ & $\begin{array}{c}\text { Mengancam } \\
\text { jiwa }\end{array}$ \\
\hline \multirow{3}{*}{ SGOT } & $1,25-$ & $2,5-5 \mathrm{x}$ & $5-10 \mathrm{x}$ & $>10 \mathrm{x}$ BAN \\
& $2,5 \mathrm{x}$ & $\mathrm{BAN}$ & $\mathrm{BAN}$ & \\
& $\mathrm{BAN}$ & & & \\
\multirow{2}{*}{ SGPT } & $1,25-$ & $2,5-5 \mathrm{x}$ & $5-10 \mathrm{x}$ & $>10 \mathrm{x}$ BAN \\
& $2,5 \mathrm{x}$ & $\mathrm{BAN}$ & $\mathrm{BAN}$ & \\
\hline
\end{tabular}

Keterangan:

BAN $=$ Batas atas normal

SGOT $=$ serum glutamic oxaloacetic transaminase

$\mathrm{SGPT}=$ serum glutamic pyruvic transaminase
Berdasarkan penelitian sebelumnya diketahui bahwa sebanyak $88 \%$ pasien HIV yang mengkonsumsi ARV mengalami abnormalitas fungsi hati, akan tetapi abnormalitas masih termasuk abnormalitas ringan. Penurunan fungsi hati pasien HIV/AIDS sterjadi pada pasien yang menggunakan nevirapin (Pathania et al, 2017). Penggunaan NRTI dan PI apat mengakibatkan perubahan metabolism seperti toksisitas pada hati, lipodistrofi dan resistensi insulin (Miller, 2009). Di Indonesia sendiri belum pernah dilakukan evaluasi fungi hati pada pasien HIV/AIDS yang mengkonsumsi ARV jangka panjang. Penelitian ini bertujuan untuk mengevaluasi fungsi hati pasien HIV/AIDS yang mengkonsumsi ARV di RSUD Mangusada.

\section{BAHAN DAN METODE}

Rancangan Penelitian. Penelitian ini merupakan penelitian cross sectional dengan pengambilan data secara retrospektif.

Bahan. Subyek Penelitian. Kriteria inklusi pada penelitian ini adalah Pasien yang didiagnosis HIV/AIDS dengan rentang usia 18-60 tahun yang melakukan pengobatan di RSUD Mangusada periode 2015 hingga 2016; dan pasien yang melakukan pemeriksaan laboratorium fungsi hati (SGPT/SGOT). Sedangkan kriteria eksklusi antara lain pasien dengan data rekam medis yang tidak lengkap, misalnya berhenti melakukan terapi pengobatan, pasien meninggal, dan pasien yang dirujuk ke rumah sakit lain.

Metode. Evaluasi fungsi hati dilakukan dengan melihat pemeriksaan fungsi hati pasien yang tercantum dalam rekam medis. Setelah data SGOT dan SGPT terkumpul maka akan dievaluasi apakah gangguan fungsi hati dengan menggunakan penggolongan toksisitas ARV yang ditetapkan oleh kementerian Kesehatan Republik Indonesia. Kemudian untuk melihat perbandingan fungsi hati masing masing regimen akan dlakukan secara statistika dengan taraf kepercayaan $95 \%$.

\section{HASIL DAN PEMBAHASAN}

Berdasarkan hasil penelitian diperoleh populasi pasien dengan diagnosa HIV/AIDS sebesar 119 pasien. Setelah melalui proses seleksi menggunakan kriteria inklusi dan eksklusi, sampel yang sesuai kriteria penelitian yaitu sebanyak 63 pasien. 
Tabel 2. Persentase Karakteristik Subyek Penelitian Berdasarkan Jenis Kelamin

\begin{tabular}{ccc}
\hline Jenis Kelamin & Jumlah & Persentase \\
\hline Laki-laki & 39 orang & $62,00 \%$ \\
\hline Perempuan & 24 orang & $38,00 \%$ \\
\hline Total & 63 orang & $100,00 \%$ \\
\hline
\end{tabular}

Bersadarkan data yang diperoleh diketahui bahwa laki laki lebih banyak menderita HIV/AIDS dibandingkan perempuan. Berdasarkan penelitian Jef Gishard Kristo Kalalo, dkk mengenai Studi Penatalaksanaan Terapi pada Penderita HIV/AIDS di Klinik VCT Rumah Sakit Kota Manado tahun 2012 menyebutkan bahwa proporsi kasus HIV/AIDS pada laki-laki lebih tinggi dibandingkan perempuan dikarenakan mayoritas pengguna jarum suntik ialah laki-laki dan pelanggan seks komersial kebanyakan adalah lakilaki (Kalalo, 2012).

Tabel 3. Persentase Karakteristik Subyek Penelitian Berdasarkan Umur

\begin{tabular}{cccc}
\hline Umur & Rentang & Jumlah & Persentase \\
\hline $\begin{array}{c}\text { Masa Remaja } \\
\text { Akhir }\end{array}$ & $\begin{array}{c}17-25 \\
\text { tahun }\end{array}$ & 4 orang & $6,35 \%$ \\
\hline $\begin{array}{c}\text { Masa Dewasa } \\
\text { Awal }\end{array}$ & $\begin{array}{c}26-35 \\
\text { tahun }\end{array}$ & 32 orang & $50,80 \%$ \\
\hline $\begin{array}{c}\text { Masa Dewasa } \\
\text { Akhir }\end{array}$ & $\begin{array}{c}36-45 \\
\text { tahun }\end{array}$ & 17 orang & $26,98 \%$ \\
\hline $\begin{array}{c}\text { Masa Lansia } \\
\text { Awal }\end{array}$ & $\begin{array}{c}46-55 \\
\text { tahun }\end{array}$ & 9 orang & $14,28 \%$ \\
\hline $\begin{array}{c}\text { Masa lansia } \\
\text { akhir }\end{array}$ & $\begin{array}{c}56-65 \\
\text { tahun }\end{array}$ & 1 orang & $1,59 \%$ \\
\hline Total & 63 orang & $100,00 \%$ \\
\hline & & &
\end{tabular}

Pasien HIV/AIDS paling banyak ditemukan pada umur 26-35 tahun (50,80\%). Berdasarkan penelitian Kurnia Fitri Jamil tahun 2014 yang menyebutkan bahwa penderita HIV/AIDS paling sering dijumpai pada usia produktif (15-49 tahun), hal ini kemungkinan karena pengaruh aktivitas seksual yang masih tinggi masa usia produktif, pengaruh lingkungan dan pekerjaan.

\begin{tabular}{lcc}
\multicolumn{3}{c}{ Tabel 4. Persentase Penggunaan Regimen ARV } \\
\hline $\begin{array}{c}\text { Nama Rejimen } \\
\text { ARV }\end{array}$ & Jumlah & Persentase \\
\hline ZDV + 3TC + NVP & 9 orang & $14,28 \%$ \\
\hline TDF + 3TC + NVP & 13 orang & $20,63 \%$ \\
\hline TDF + 3TC + EFV & 36 orang & $57,14 \%$ \\
\hline $\mathrm{d} 4 \mathrm{~T}+3 \mathrm{TC}+\mathrm{EFV}$ & 1 orang & $2,80 \%$ \\
\hline TDF + 3TC + PI & 1 orang & $1,58 \%$ \\
\hline $\mathrm{ZDV}+3 \mathrm{TC}+\mathrm{EFV}$ & 3 orang & $6,37 \%$ \\
\hline Total & 63 orang & $100,00 \%$ \\
\hline
\end{tabular}

Keterangan:

TDF : Tenofovir

3TC : Lamivudine
NVP : Nevirapine

EFV : Efavirenz

d4T : stavudin

ZDV : Zidovudine

PI : Aluvia ${ }^{\circledR}$ (lopinavir dan ritonavir)

Gambaran pengobatan terapi yang digunakan pada pasien HIV/AIDS yaitu menggunakan terapi antiretroviral. Penggunaan terapi ARV terdapat pada tabel (4.3), menunjukkan bahwa penggunaan regimen TDF $+3 \mathrm{TC}+\mathrm{EFV}$ mempunyai persentase penggunaan yang paling besar yaitu sebanyak $57,14 \%$. Penggunaan rejimen $\mathrm{TDF}+3 \mathrm{TC}+\mathrm{EFV}$ disediakan dalam kemasan FDC (Fix Dose Combination) atau yang sering diartikan kombinasi beberapa obat dalam satu pil. Berdasarkan Pedoman Nasional Tatalaksana Klinis Infeksi HIV dan Terapi Antiretroviral pada Orang Dewasa Tahun 2014 dan berdasarkan rekomendasi WHO (2013) dijelaskan bahwa AZT atau TDF + 3TC (atau FTC) + EFV atau NVP merupakan pilihan paduan lini pertama yang sesuai untuk pasien dewasa, sehingga regimen ini yang paling sering digunakan sebagai pilihan terapi untuk pasien HIV/AIDS (Kemenkes, 2014; WHO, 2013).

Tabel 5 Derajat Toksisitas Hepar berdasarkan parameter SGOT

\begin{tabular}{clcc}
\hline NO & Keterangan & Jumlah & Persentase \\
\hline 1 & $\begin{array}{l}\text { Normal/ tidak } \\
\text { toksik }\end{array}$ & 53 & 84,10 \\
\hline 2 & $\begin{array}{l}\text { Toksisitas } \\
\text { ringan }\end{array}$ & 7 & 11,10 \\
\hline 3 & $\begin{array}{l}\text { Toksisitas } \\
\text { sedang }\end{array}$ & 3 & 4,80 \\
\hline & Total & 63 & 100,00 \\
\hline
\end{tabular}

Berdasarkan data SGOT yang diperoleh tidak terdapat kejadian hepatotoksisitas yang mengancam jiwa. Sebagian besar tidak mengalami toksisitas $(84,10 \%)$.

Tabel 6 Derajat Toksisitas Hepar berdasarkan parameter SGPT

\begin{tabular}{clcc}
\hline NO & Keterangan & Jumlah & Persentase \\
\hline 1 & $\begin{array}{l}\text { Normal/ tidak } \\
\text { toksik }\end{array}$ & 53 & 84,10 \\
\hline 2 & $\begin{array}{l}\text { Toksisitas } \\
\text { ringan }\end{array}$ & 6 & 9,50 \\
\hline 3 & $\begin{array}{l}\text { Toksisitas } \\
\text { sedang }\end{array}$ & 4 & 6,30 \\
\hline & Total & 63 & 100,00 \\
\hline
\end{tabular}

Berdasarkan data SGPT yang diperoleh tidak terdapat kejadian hepatotoksisitas yang mengancam jiwa. Sebagian besar tidak mengalami 
toksisitas $(84,10 \%)$. Berdasarkan tabel 5 dan tabel 6 diketahui bahwa secara keseluruhan fungsi hati dari pasien HIV/AIDS mayoritas masih normal (84,10\% SGPT dan SGOT normal). Tidak terdapat pasien yang mengalami toksisitas berat maupun toksisitas yang mengancam jiwa.

Salah satu obat ARV yang diduga bertanggung jawab terhadap timbulnya efek hepatotoksik adalah Nevirapine. Sebuah penelitian di India pada tahun 2017 menyatakan bahwa penggunaan Nevirapine dapat mengakibatkan timbulnya abnormalitas fungsi hati (Pathania et al, 2017).

Tabel 7 Penggunaan Nevirapine

\begin{tabular}{clcc}
\hline NO & Penggunaan & Jumlah & Persentase \\
\hline 1 & $\begin{array}{l}\text { Dengan } \\
\text { nevirapin }\end{array}$ & 42 & 66,70 \\
\hline 2 & Tanpa nevirapin & 21 & 33,30 \\
\hline & Total & 63 & 100,00 \\
\hline
\end{tabular}

Berdasarkan tabel 7 sebanyak 66,70\% pasien menggunakan nevirapine. Nevirapine masih digunakan sebagai regimen ARV di Indonesia dan di dunia.

Tabel 8 Analisis toksisitas penggunaan nevirapin

\begin{tabular}{|c|c|c|c|c|}
\hline & $\begin{array}{c}\text { SGOT } \\
\text { normal }\end{array}$ & $\begin{array}{c}\text { SGOT } \\
\text { meningkat }\end{array}$ & total & $\mathbf{p}$ \\
\hline $\begin{array}{c}\text { Dengan } \\
\text { nevirapin }\end{array}$ & 35 & 7 & 42 & \multirow{3}{*}{$\left.1,000^{*}\right)$} \\
\hline $\begin{array}{c}\text { Tanpa } \\
\text { nevirapin }\end{array}$ & 18 & 3 & 21 & \\
\hline Total & 53 & 10 & 63 & \\
\hline
\end{tabular}

*) uji Fisher dengan taraf kepercayaan $95 \%$

Berdasarkan hasil uji Fisher pada tabel 8 diketahui bahwa tidak terdapat hubungan yang signifikan antara penggunaan nevirapine dengan peningkatan SGOT ( $p>0,05)$.

Tabel 9 Analisis toksisitas penggunaan nevirapin ditinjau dari SGPT

\begin{tabular}{|c|c|c|c|c|}
\hline & $\begin{array}{c}\text { SGPT } \\
\text { normal }\end{array}$ & $\begin{array}{c}\text { SGPT } \\
\text { meningkat }\end{array}$ & total & $\mathbf{p}$ \\
\hline $\begin{array}{c}\text { Dengan } \\
\text { nevirapin }\end{array}$ & 35 & 7 & 42 & \multirow{3}{*}{$1,000 *)$} \\
\hline $\begin{array}{c}\text { Tanpa } \\
\text { nevirapin }\end{array}$ & 18 & 3 & 21 & \\
\hline Total & 53 & 10 & 63 & \\
\hline
\end{tabular}

*) uji Fisher dengan taraf kepercayaan $95 \%$

Berdasarkan hasil uji Fisher pada tabel 9 diketahui bahwa tidak terdapat hubungan yang signifikan antara penggunaan nevirapine dengan peningkatan SGPT (p>0,05). Dan berdasarkan uji fisher penggunaan nevirapin tidak berpengaruh secara signifikan terhadap toksisitas hepar apabila ditinjau dari parameter SGOT dan SGPT p>0,05; OR 0,833 (CI 0,192-3,614).

Berdasarkan penelitian yang dilakukan oleh Vincent Soriano, dkk pada tahun 2008 menyatakan bahwa golongan NRTI dapat dikaitkan dengan angka tinggi hepatotoksisitas sedang sampai berat, berkisar $7 \%$ dengan penggunaan Zidovudine sementara pada penggunaan Nevirapine, kejadian keseluruhan peristiwa bergejala yang melibatkan enzim hati adalah kurang lebih 5\%. Pola kerusakan penggunaan Nevirapine muncul dengan peningkatan enzim hati dalam kurun waktu lebih dari 16 minggu penggunaan terapi.

Gangguan fungsi hati pada pasien HIV/AIDS adalah kondisi yang kompleks dan dapat dipengaruhi oleh banyak faktor (Sherman et al, 2017). Berdasarkan penelitian yang dilakukan oleh Pathania dkk tahun 2017, abnormalitas peningkatan fungsi hati dapat terjadi akibat penggunaan nevirapin pada pasien HIV/AIDS. Abnormalitan enzim hati yang terjadi mayoritas berupa toksisitas hepar ringan dan sedang dengan peningkatan kadar enzim hari 2,6 hingga 5 kali dari nilai normal. Kasus kerusakan hati parah akibat penggunaan nevirapine dapat terjadi apabila pasien juga mengkonsumsi obat anti TBC di saat yang bersamaan . selain itu konsumsi alkohal dan adanya koinveksi virus hepatitis juga dapat memperparah kondisi kerusakan hepar pada pasien HIV/AIDS (Pathania et al, 2017; Sherman et al, 2017).

\section{SIMPULAN}

Simpulan yang dapat ditarik dari penelitian yang telah dilakukan yaitu bahwa sebanyak 84,10 pasien HIV/AIDS yang memperoleh terapi ARV tidak mengalami gangguan hepar, sisanya mengalami toksisitas ringan dan sedang. Penggunaan nevirapin tidak berpengaruh secara signifikan terhadap peningkatan SGOT dan SGPT.

\section{DAFTAR PUSTAKA}

Arikunto, Suharsini. 2006, Prosedur Penelitian Suatu Pendekatan Praktik, Jakarta: Rineka Cipta.

Departemen Kesehatan Republik Indonesia. 2012, Profil Kesehatan Indonesia. Jakarta, Kementerian Kesehatan Republik Indonesia. 
Ditjen PPM dan PL Depkes Republik Indonesia. 2011, Panduan Tatalaksana Klinis Infeksi HIV dan Terapi Antiretroviral pada orang Dewasa, Jakarta, Kemenkes RI Direktorat Jenderal Pengendalian Penyakit dan Penyehatan Lingkungan.

Jamil, Kurnia Fitri. 2014. Profil Kadar CD4 Terhadap Infeksi Oportunistik pada penderita Human Immunodeficiency Virus/Asquired immunodeficiency Syndrome (HIV/AIDS) di RSUD DR. Zainoel Abidin Banda Aceh. Aceh: Jurnal kedokteran Syiah Kuala.

Kalalo, Jef Gishard Kristo, dkk. 2012. Studi Penatalaksaan Terapi Pada Penderita HIV/AIDS di Klinik VCT Rumah Sakit Kota Manado. Manado, Universitas Sam Ratulangi.

Kementerian Kesehatan Republik Indonesia. 2011, Profil Data Kesehatan Indonesia Tahun 2011, Jakarta, Kementerian Kesehatan Republik Indonesia.

Kementerian Kesehatan Republik Indonesia. 2011, Perauran Menteri Kesehatan NO 87 tahun 2014 tentang pedoman pengobatan antiretroviral, Jakarta, Kementerian Kesehatan Republik Indonesia.

Pathania,S.M., Sqn Ldr Navjyot Kaur, Maj Sandeep Kumar, Air Cmde V.K. Sashindran, Brig Pankaj Puri, 2017, A
Crossectional Study of Liver Function Test in HIV infected Person In Western India, Medical Journal Armed Force India 73(23-28).

Sherman, K.E., Peters, M.G. and Thomas, D., 2017. Human immunodeficiency virus and liver disease: A comprehensive update. Hepatology communications, 1(10), pp.987-1001.

Soriano, Vincent., Puoti Massimo, Barreiro Pablo. 2008, Obat Antiretroviral dan Kerusakan Hati, AIDS 2008;22(1):1-13

Sukandar, E. Y., Andrajati, R., Sigit, J. I., Adnyana, I. K., Setiadi, A. P. \& Kusnandar. 2008, ISO Farmakoterapi. Jakarta, Ikatan Sarjana Farmasi Indonesia.

UNAIDS. 2011, Global Report: UNAIDS report on the global AIDS epidemic 2011, Geneva, Joint United Nations Programme on HIV/AIDS.

World Health Organization. 2007, WHO Community Home Base Care In Resource Limited Setting, The Department of HIV/AIDS, Family And Community Health, Switzerland, WHO.

World Health Organization. 2016, Global AIDS update 2016, UNAIDS. Switzerland, WHO. 